\title{
COVID-19 Pandemic and Its Impact on Population Mental Health
}

\author{
Aymen Elsous ${ }^{1,2}$, Amira Shaheen ${ }^{3}$, Hedia Teraoui ${ }^{4}$, Shahenaz Najjar ${ }^{5}$, Suha Baloushah ${ }^{6,7}$, \\ Kahina Mekious ", Mahmoud Radwan", , Mohammad Abu Rayya ${ }^{10}$ \\ ${ }^{1}$ Faculty of Medical Sciences, Israa University, Gaza Strip, Palestine \\ ${ }^{2}$ Unit of Planning and Policy Formulation, Ministry of Health, Gaza Strip, Palestine \\ ${ }^{3}$ Public Health Department, Faculty of Medicine and Health Sciences, An-Najah National University, Nablus, Palestine \\ ${ }^{4}$ Research Laboratory of Risk Management and Research in Accounting and Finance, High Business School, University of Manouba, \\ Manouba, Tunisia \\ ${ }^{5}$ Faculty of Graduate Studies, Arab American University, Ramallah, Palestine \\ ${ }^{6}$ Reproductive Health Department, Nursing and Midwifery School, Tehran University of Medical Sciences, Tehran, Iran \\ ${ }^{7}$ Health Profession Department, Intermediate Study College, Al-Azhar University, Gaza Strip, Palestine \\ ${ }^{8}$ Yazouren Said Secondary School, Azazga, Tizi Ouzou, Algeria \\ ${ }^{9}$ International Cooperation Directorate, Ministry of Health, Gaza Strip, Palestine \\ ${ }^{10}$ Expert Modernity Consulting and Community Development, Gaza Strip, Palestine
}

\section{Email address:}

aymenelsous65@gmail.com (A. Elsous),amira.shaheen@najah.edu(A. Shaheen), hedia.teraaoui@esct.uma.tn(H. Teraoui), shnajjar@gmail.com (S. Najjar), sbaloushah@gmail.com (S. Baloushah), doudouchd83@gmail.com (K. Mekious),

mradwan78@hotmail.com (M. Radwan),mohammadaburayya99@hotmail.com (M. A. Rayya)

${ }^{*}$ Corresponding author

\section{To cite this article:}

Aymen Elsous, Amira Shaheen, Hedia Teraoui, Shahenaz Najjar, Suha Baloushah, Kahina Mekious, Mahmoud Radwan, Mohammad Abu Rayya. COVID-19 Pandemic and Its Impact on Population Mental Health. International Journal of Psychological and Brain Sciences. Vol. 5, No. 6, 2020, pp. 83-91. doi: 10.11648/j.ijpbs.20200506.11

Received: November 18, 2020; Accepted: November 30, 2020; Published: December 11, 2020

\begin{abstract}
The novel Coronavirus (COVID-19) was recognized as pandemic and posed a risk on populations' mental health status. This study aimed to examine anxiety experience, attitudes and perceived mental health care needs of Arabs populations under COVID-19 pandemic. Online cross-sectional study was employed to collect data from Palestinians and Tunisians using a self-reported questionnaire and following non-probability snow ball sampling approach. Descriptive and univariate analyses were applied. Eight hundred fifteen subjects responded, of which 534 from Palestine and 281 from Tunisia and mean age (SD) was 34.07 (11.36) and 27.94 (9.30), respectively. Palestinians and Tunisians showed positive attitudes toward COVID-19 with mean (SD) 4.28 (.47) and 4.17 (.45), respectively. Mean (SD) anxiety score was 2.94 (.67) and 3.30 (.69) in participants from Palestine and Tunisia, respectively and severe anxiety was reported in $6.7 \%$ and $16 \%$ among Palestinians and Tunisians, respectively. Both Palestinians and Tunisians agreed on the importance of seeking and receiving aid from mental health professionals to combat COVID-19. Attitudes improved with increased education and females showed to have better attitudes and much anxiety than males. Addressing mental health issues is necessary for population under the pandemic of COVID-19 to minimize anxiety level and ensure better mental health status.
\end{abstract}

Keywords: Novel Coronavirus, Attitudes, Anxiety, Mental Health, Palestine, Tunisia

\section{Introduction}

An outbreak of respiratory disease of unknown cause was first reported in China, Wuhan city, in late December 2019. Later, a novel coronavirus was identified as the causative pathogen and named 2019 new coronavirus (2019- nCOV) 
then changed to COVID-19. The virus spread dramatically and cross boarder leading to toll of morbidity and mortality [1]. By February 2020, the virus reached at least 25 countries and majority of cases with positive COVID-19 remained in China [2] On March 2020, the world Health Organization (WHO) announced the novel coronavirus (COVID-19) a pandemic. With the reporting of the first cases of COVID-19 in Palestine and Tunisia, early March. The two governments took, almost, similar protective measures to contain the pandemic, and overwhelming on the fragile health system. State of emergency was announced, followed by the closure of the boarder, restricting the population movement, except for essentials such as buying groceries, and seeking urgent medical care. Population in these two countries continuously received health massages that emphasized at the importance of staying at home, wearing face mask while outside, washing hands, and social distancing $[3,4]$.

Peoples' attitudes play a role in success of governments' efforts to contain the spread of the virus. Several studies were found to assess the attitude towards protective measures in the population as well as specific occupational category. Moderate attitude towards control and preventive measures was observed among general population like in Saudi Arabia. Participants indicated that social distancing, washing hands, staying at home, and complying with ministry of health measures would help in containing the spread of COVID-19 in their country [5]. Chinese are very confident about controlling the spread of COVID-19 pandemic, and ability of their government to win the battle against it [6]. Workers of public sector in Malaysia showed optimistic attitude towards the containing of COVID19 pandemic by their government. They were very confident that COVID-19 will be controlled, and their government is handling the health crises very well, hence their country will manage to overcome it [7]. Positive attitude towards washing hands and isolating themselves when get infected was reported among health care providers in Ho Chi Minh City, Vietnam [8]. On the other hand, healthcare workers in Uganda showed negative attitudes towards face mask, hand washing, and ability of government to contain the COVID-19 [9].

Previous pandemics, like Ebola and SARS, imposed immediate physical and mental illness, including stress and anxiety, resulted from extreme pressure on general public [10, 11]. The novel coronavirus is shown to have similar impact on population mental health. The uncertainty evolving in COVID19 caused severe psychological pressure and serious health problems [12-14]. High transmissibility, potential risk of death, mass quarantine, and social distance increase the panic, stress, depression and anxiety level [10, 15-17]. Brooks and his colleagues reported quarantine could bring posttraumatic stress symptoms, confusion, and anger [18]. Stressors included longer quarantine duration, infection fears, frustration, boredom, inadequate supplies, inadequate information, financial collapse, and stigma [18]. Loneliness, rejection, insomnia and hopelessness symptoms were also reported [19]. People with chronic diseases are highly susceptible for psychological distresses during COVID-19 pandemic [14]. Aggressive attitudes and may develop and result in suicide attempts $[7,20]$.
Limited studies on mental health impact of COVID-19 pandemic among Arabs general population are existed [21]. The aim of the current study is to investigate and compare Palestinians and Tunisians' attitudes toward COVID-19, anxiety experience, and perception of mental health care needs during the COVID-19 pandemic.

\section{Methods}

\subsection{Study Design}

The study was online cross-sectional observation study.

\subsection{Study Setting}

The study was carried out in Palestine and Tunisia. Both are Arabic speaking countries which include 22 countries extend from gulf area to Atlantic Ocean. Palestine locates in Middle East area in Asia continent, while Tunisia is in Arica and is a Mediterranean country.

\subsection{Study Sample and Sampling}

Eight hundred fifteen subjects from population participated (534 from Palestine and 280 From Tunisia). A snowball sampling was followed to recruit wide number of participants. Participants' inclusion criteria included access to internet, be above 18 years old, willing to participate and understand Arabic.

\subsection{Measures}

A semi-structured questionnaire was developed and prepared for online distribution. Studies of [18, 22, 23] were a base for development of the questionnaire. The tool composed of four sections; first part was about sociodemographic data (age, gender, profession, education level,..); second part measured attitudes toward people infected with COVID-19 and contained six statements of which two were reversed questions; third part measured anxiety from COVID-19 and had 17 questions. Statements of the two sections were measured on five point Likert scale (1= never to $5=$ always). The last part examined the need for mental healthcare services with four statements which were measured on three point scale (No, May be, Yes). The questionnaire was translated to Arabic and then validated. The internal consistency of the whole questionnaire was good enough (alpha cronbach 0.78 and ranged from 0.73 to 0.87 ). The questionnaire was content valid. The scale and item contend validity index [(S-CVI), (I-CVI)] were examined and ranged between 0.924 and 0.974 , and 0.88 to 1.00 , respectively. The questionnaire is available in Arabic at: https://docs.google.com/forms/d/e/1FAIpQLSevYEWQv8XbbUQyXXOijFEt18j8WdKcsBjgOJrCWg3Wje8A/viewform.

\subsection{Data Collection and Ethical Considerations}

The questionnaire was developed by using Google forum and the link was first distributed to authors whom forwarded it to their contact list. Participants were also stimulated to pass the 
link to as many people as possible. The link of survey was also posted in WhatsApp and Facebook groups. Every participant read in advance a cover letter attached to questionnaire which includes information about the study and its objective, the voluntary participation and anonymity of individual and the right to discontinue if feeling discomfort with the survey. Finally, participants had to give consent prior filling the survey. Average time to fill the survey was 12 minutes at most. Data were collected from 1st June to 23rd June, 2020.

\subsection{Data Analysis}

Data were first extracted and then analyzed using SPPS software version 22. Data were checked for missing and outliers. Nine questionnaires were excluded of which five because missing values were above $5 \%$ and four because age of participants was below 18 years. The demographic data and scores of the attitudes, anxiety were summarized using descriptive statistics. Continuous variable (age) was presented informs of mean and standard deviation. Categorical variables (gender, occupation, education level,..) were presented as frequency and percentage. With regard to attitudes, questions "Traveling within country is safe at these times" and "Patients recovered from Covid-19 are not allowed to stay within community at these times" were reversed questions. In addition, participants who responded never, occasionally were considered to have negative attitude, whereas, answers of sometimes, often and always were considered as positive attitude. Anxiety was classified into no anxiety (answer never), mild to moderate (occasionally and sometimes) and severe anxiety (often and always). Univariate analysis was applied to compare mean differences of attitudes and anxiety with regard to independent variables (gender, age, job and education) and confidence interval at $95 \%$ was presented.

\section{Results}

\subsection{Characteristics of Participants}

The survey was completed by 815 participants, of which 534 were from Palestine and 281 from Tunisia and the mean age (SD) was 34.07 (11.36) and 27.94 (9.30), respectively. Distribution of males and females in both samples was equal and most participants, from Palestine and Tunisia had university degree (Table 1). Majority of participants (>95\%), from both countries, have neither been exposed to the novel coronavirus nor their families. Moreover, they did not contact persons infected with novel coronavirus. Quite $40 \%$ of participants from Palestine and 36\% from Tunisia did receive training on infection prevention and control about Covid-19.

Table 1. Baseline characteristics of participated subjects.

\begin{tabular}{lll}
\hline \multirow{2}{*}{ Variables } & Palestine $(\mathbf{N}=\mathbf{5 3 4})$ & Tunisia $(\mathbf{N}=\mathbf{2 8 1})$ \\
\cline { 2 - 3 } & $\mathbf{n}(\mathbf{\%})$ & $\mathbf{n}(\mathbf{\%})$ \\
\hline Age $(\mathrm{M} \pm \mathrm{SD})$ & $34.07 \pm 11.36$ & $27.94 \pm 9.30$ \\
$\leq 35$ & $318(59.6)$ & $214(76.2)$ \\
$>35$ & $212(39.7)$ & $35(23.1)$ \\
Gender & & \\
Male & $177(33.1)$ & $93(33.1)$ \\
Female & $356(66.7)$ & $188(66.9)$ \\
Job & & \\
Healthcare provider & $151(28.3)$ & $12(4.3)$ \\
Business & $10(1.9)$ & $7(2.5)$ \\
Academia & $71(13.3)$ & $27(9.6)$ \\
Professional / crafts & $12(2.2)$ & $10(3.6)$ \\
Student & $101(18.9)$ & $166(59.1)$ \\
Housewife & $64(12.0)$ & $13(4.6)$ \\
Un-employed & $0(0)$ & $0(0)$ \\
Others & $122(22.8)$ & $44(15.7)$ \\
Education level & & \\
Up to secondary school & $46(8.7)$ & $22(7.9)$ \\
Technical/college & $17(3.2)$ & $9(3.2)$ \\
University and above & $471(88.2)$ & $250(89.0)$ \\
\hline
\end{tabular}

\subsection{Attitudes Toward COVID-19 pandemic}

Participants from Palestine and Tunisia showed to have positive attitudes; 85.65 and $83.4 \%$, respectively. Majority $(>95 \%)$, from both countries, perceived social distance and hand-washing necessity to prevent spread of Covid-19. They were willing to isolate their selves when symptoms like cough and fever appear. Almost one quarter disagreed about persons recovered from the new coronavirus to not remain or stay within community (Table 2).

Table 2. Participants' attitudes toward Covid-19 pandemic.

\begin{tabular}{|c|c|c|c|c|c|c|}
\hline \multirow[b]{2}{*}{ Item } & \multicolumn{3}{|c|}{ Palestine $(\mathrm{N}=534)$} & \multicolumn{3}{|l|}{ Tunisia $(\mathrm{N}=281)$} \\
\hline & $\mathbf{M} \pm \mathbf{S D}$ & $\begin{array}{l}\text {-ve attituden } \\
(\%)\end{array}$ & $\begin{array}{l}\text { +ve attitude } \\
\text { n }(\%)\end{array}$ & $\begin{array}{l}\mathrm{M} \pm \mathrm{SD} \\
(\% \text { mean })\end{array}$ & $\begin{array}{l}\text {-ve attitude } \\
\text { n (\%) }\end{array}$ & $\begin{array}{l}\text { +ve attitude } \\
\text { n (\%) }\end{array}$ \\
\hline $\begin{array}{l}\text { I think frequent hand-washing reduces the risk of infection } \\
\text { with Covid-19 }\end{array}$ & $4.52 \pm .76$ & $6(1.1)$ & $526(98.5)$ & $4.46 \pm .78(89.2)$ & $5(1.8)$ & $276(98.2)$ \\
\hline $\begin{array}{l}\text { I think social distance is necessary to prevent spread of new } \\
\text { coronavirus }\end{array}$ & $4.68 \pm .70$ & $10(1.9)$ & $523(97.9)$ & $4.67 \pm .68(93.4)$ & $6(2.1)$ & 275 (97.9) \\
\hline $\begin{array}{l}\text { I think I will isolate or quarantine myself if symptoms of } \\
\text { fever and cough appear }\end{array}$ & $4.6 \pm .92$ & $23(4.3)$ & $511(95.7)$ & $4.68 \pm .78(93.6)$ & $6(2.1)$ & $275(97.9)$ \\
\hline $\begin{array}{l}\text { *I believe patients recovered from Covid-19 are not allowed } \\
\text { to stay within community at these times }\end{array}$ & $3.62 \pm 1.40$ & $128(24.0)$ & $405(75.8)$ & $3.38 \pm 1.43(67.6)$ & $84(29.9)$ & $196(69.8)$ \\
\hline $\begin{array}{l}\text { I agree about government instructions and interventions } \\
\text { related to Covid-19 }\end{array}$ & $4.41 \pm .97$ & $31(5.8)$ & $503(94.2)$ & $4.28 \pm 1.05(85.6)$ & $20(7.1)$ & $261(92.9)$ \\
\hline *I think Traveling within country is safe at these times & $3.98 \pm 1.20$ & $82(15.4)$ & $452(84.6)$ & $3.52 \pm 1.30(70.4)$ & $75(26.7)$ & $206(73.3)$ \\
\hline Mean score (SD) & $4.28(.47)$ & & & $4.17(.45)$ & & \\
\hline
\end{tabular}

*reverse question 


\subsection{Anxiety Level Toward COVID-19 Pandemic}

Majority of participants had some form of anxiety. Mild to moderate and severe anxiety were reported in $83.7 \%$ vs. $6.7 \%$ and $74.7 \%$ vs. $16 \%$ in participants from Palestine and Tunisia, respectively. More than half of Palestinians and Tunisians felt worrying most of time about their selves and close ones regarding the spread of new coronavirus $(51.9 \%$ vs. $62.3 \%$, respectively). Three quarters of participated Palestinians and Tunisians felt most time in-need to wash their hands frequently. Sleeping pattern was severely affected by COVID-19 in $6.9 \%$ and $14.6 \%$ of participated Palestinians and Tunisians, respectively. More than half from both countries used most of time a mask without clear signs and symptoms of the infection (Table 3, Table 4).

Table 3. Anxiety level toward Covid-19 pandemic in Palestine.

\begin{tabular}{|c|c|c|c|c|}
\hline Items In the last week, & $\mathbf{M} \pm \mathbf{S D}$ & $\begin{array}{l}\text { No anxiety } \\
\text { n (\%) }\end{array}$ & $\begin{array}{l}\text { Mild-moderate } \\
\text { n (\%) }\end{array}$ & $\begin{array}{l}\text { Severe } \\
\text { n (\%) }\end{array}$ \\
\hline $\begin{array}{l}\text { How often you felt worrying about yourself, and close ones regarding the spread } \\
\text { of new coronavirus? }\end{array}$ & $3.81 \pm 1.21$ & $82(15.4)$ & $174(32.6)$ & $277(51.9)$ \\
\hline $\begin{array}{l}\text { How often you were affected by the talks of news channels and newspaper on } \\
\text { Covid-19 pandemic }\end{array}$ & $3.27 \pm 1.18$ & $38(7.1)$ & $235(44.0)$ & $259(48.5)$ \\
\hline To what extent you avoided large meetings? & $3.36 \pm 1.19$ & $41(7.7)$ & $219(41.0)$ & $274(35.1)$ \\
\hline how often you have talked to your friends about the Covid-19 pandemic & $2.81 \pm 1.19$ & $73(13.7)$ & $304(56.9)$ & $157(29.4)$ \\
\hline How often you thought about Covid-19? & $2.79 \pm 1.21$ & $73(13.7)$ & $311(58.2)$ & $150(28.1)$ \\
\hline How often you felt afraid from contacting persons infected with Covid-19? & $2.87 \pm 1.47$ & $149(27.9)$ & $171(32.0)$ & $212(39.7)$ \\
\hline $\begin{array}{l}\text { How often you were affected by the posts on social media about Covid-19 } \\
\text { infection? }\end{array}$ & $3.11 \pm 1.20$ & $61(11.4)$ & $243(45.5)$ & $228(42.7)$ \\
\hline How often you felt you were in-need to buy and stock all essentials at home? & $2.17 \pm 1.22$ & $222(41.6)$ & $222(41.6)$ & $89(16.7)$ \\
\hline $\begin{array}{l}\text { How often you faced difficulty sleeping resulted from worrying about the } \\
\text { Covid-19 pandemic? }\end{array}$ & $1.59 \pm 1.01$ & $355(66.2)$ & $140(26.2)$ & $37(6.9)$ \\
\hline $\begin{array}{l}\text { How often you're frightening from Covid-19 infection lead to inappropriate } \\
\text { behaviors with anyone? }\end{array}$ & $2.06 \pm 1.24$ & $258(48.3)$ & $196(36.7)$ & $78(14.6)$ \\
\hline I felt I might be infected with new coronavirus & $2.39 \pm 1.19$ & $159(29.8)$ & $286(53.6)$ & $87(16.3)$ \\
\hline To what extent you avoided partying? & $3.42 \pm 1.35$ & $63(11.8)$ & $174(32.6)$ & $297(55.6)$ \\
\hline $\begin{array}{l}\text { How often you felt frightening if anyone from social circle reported of being } \\
\text { sick? }\end{array}$ & $3.33 \pm 1.39$ & $82(15.4)$ & $174(32.6)$ & $377(51.8)$ \\
\hline How often you felt in-need to use the sanitizer/gloves? & $3.39 \pm 1.26$ & $39(7.3)$ & $221(41.4)$ & $273(51.1)$ \\
\hline How often you felt in-need to wash your hands frequently? & $4.16 \pm 1.08$ & $9(1.7)$ & $105(19.7)$ & $420(78.7)$ \\
\hline To what extent you avoided contacting people? & $2.92 \pm 1.23$ & $85(15.9)$ & $252(47.2)$ & $197(36.9)$ \\
\hline How often you used a mask without clear signs and symptoms of the infection? & $2.45 \pm 1.29$ & $39(7.3)$ & $221(41.3)$ & $273(51.2)$ \\
\hline Over all & $\mathrm{M}(\mathrm{SD}) 2.94(.67)$ & $34(6.4)$ & $447(83.7)$ & $36(6.7)$ \\
\hline
\end{tabular}

Table 4. Anxiety level toward Covid-19 pandemic in Tunisia

\begin{tabular}{|c|c|c|c|c|}
\hline Items In the last week, & $\mathbf{M} \pm \mathbf{S D}$ & $\begin{array}{l}\text { No anxiety } \\
\text { n }(\%)\end{array}$ & $\begin{array}{l}\text { Mild-moderate } \\
\text { n (\%) }\end{array}$ & $\begin{array}{l}\text { Severe } \\
\text { n }(\%)\end{array}$ \\
\hline $\begin{array}{l}\text { How often you felt worrying about yourself, and close ones regarding the } \\
\text { spread of new coronavirus? }\end{array}$ & $4.22 \pm 1.09$ & $26(9.3)$ & $79(28.1)$ & $175(62.3)$ \\
\hline $\begin{array}{l}\text { How often you were affected by the talks of news channels and newspaper on } \\
\text { Covid- } 19 \text { pandemic }\end{array}$ & $3.50 \pm 1.21$ & $22(7.8)$ & $100(35.6)$ & $156(55.5)$ \\
\hline To what extent you avoided large meetings? & $3.74 \pm 1.18$ & $14(5.0)$ & $84(29.9)$ & $180(64.1)$ \\
\hline how often you have talked to your friends about the Covid-19 pandemic & $3.06 \pm 1.15$ & $26(9.3)$ & $155(55.2)$ & $98(34.9)$ \\
\hline How often you thought about Covid-19? & $3.03 \pm 1.22$ & $27(9.6)$ & $160(56.9)$ & $93(33.1)$ \\
\hline How often you felt afraid from contacting persons infected with Covid-19? & $3.31 \pm 1.36$ & $42(14.9)$ & $98(34.9)$ & $139(49.4)$ \\
\hline $\begin{array}{l}\text { How often you were affected by the posts on social media about Covid-19 } \\
\text { infection? }\end{array}$ & $3.41 \pm 1.25$ & $22(7.8)$ & $100(35.6)$ & $156(55.5)$ \\
\hline How often you felt you were in-need to buy and stock all essentials at home? & $2.25 \pm 1.35$ & $121(43.1)$ & $100(35.6)$ & $58(20.6)$ \\
\hline $\begin{array}{l}\text { How often you faced difficulty sleeping resulted from worrying about the } \\
\text { Covid-19 pandemic? }\end{array}$ & $1.93 \pm 1.27$ & $159(56.6)$ & $80(28.5)$ & $40(14.2)$ \\
\hline $\begin{array}{l}\text { How often you're frightening from Covid-19 infection lead to inappropriate } \\
\text { behaviors with anyone? }\end{array}$ & $2.46 \pm 1.42$ & $110(39.1)$ & $91(32.4)$ & $78(27.8)$ \\
\hline I felt I might be infected with new coronavirus & $2.75 \pm 1.20$ & $45(16.0)$ & $169(60.1)$ & $66(23.5)$ \\
\hline To what extent you avoided partying? & $3.90 \pm 1.29$ & $25(8.9)$ & $60(21.4)$ & $194(69.0)$ \\
\hline $\begin{array}{l}\text { How often you felt frightening if anyone from social circle reported of being } \\
\text { sick? }\end{array}$ & $3.70 \pm 1.32$ & $6(2.1)$ & $57(20.3)$ & $215(76.5)$ \\
\hline How often you felt in-need to use the sanitizer/gloves? & $3.89 \pm 1.08$ & $5(1.8)$ & $85(30.2)$ & $189(67.3)$ \\
\hline How often you felt in-need to wash your hands frequently? & $4.08 \pm 1.03$ & $2(0.7)$ & $66(23.5)$ & $210(74.7)$ \\
\hline To what extent you avoided contacting people? & $3.32 \pm 1.29$ & $30(10.7)$ & $112(39.9)$ & $136(48.4)$ \\
\hline How often you used a mask without clear signs and symptoms of the infection? & $3.56 \pm 1.23$ & $20(7.1)$ & $95(33.8)$ & $165(58.7)$ \\
\hline Overall & $\mathrm{M}(\mathrm{SD}) 3.30(.69)$ & $7(2.5)$ & $210(74.7)$ & $45(16.0)$ \\
\hline
\end{tabular}




\subsection{Perception About Importance of Mental Healthcare}

Of the participated Palestinians, 73.8\% thought about necessity to seek mental health professionals' aid among individuals being traumatized with covid-19 pandemic compared to $78.6 \%$ from Tunisia. Almost one fifth disagreed about talking to mental health professionals and to express the concern on coronavirus pandemic and risk of infection (21.5\% vs $19.9 \%$ in Palestine and Tunisia, respectively). Only 9.4\% (50/534) of participants from Palestine saw no benefits from mental health interventions compared to $6.8 \%$ $(19 / 281)$ from Tunisia (Table 5).

Table 5. Perception about mental healthcare needs.

\begin{tabular}{|c|c|c|c|c|c|c|}
\hline \multirow{2}{*}{ Items } & \multicolumn{3}{|c|}{ Palestine $(\mathrm{N}=534)$} & \multicolumn{3}{|c|}{ Tunisia $(\mathrm{N}=\mathbf{2 8 1})$} \\
\hline & No n (\%) & May be n (\%) & Yes n (\%) & No n (\%) & May be n (\%) & Yes n (\%) \\
\hline $\begin{array}{l}\text { It is necessary to seek mental health professional help if } \\
\text { someone is traumatized by the Corona pandemic }\end{array}$ & $43(8.1)$ & $95(17.8)$ & $394(73.8)$ & $14(5.0)$ & $44(15.7)$ & $221(78.6)$ \\
\hline $\begin{array}{l}\text { It is a good idea to talk to mental health specialist about your } \\
\text { concerns on the emerging epidemic of the Coronavirus }\end{array}$ & $115(21.5)$ & $165(30.9)$ & $253(47.4)$ & $56(19.9)$ & $88(31.3)$ & $134(47.7)$ \\
\hline $\begin{array}{l}\text { I see benefit from help and intervention of mental health } \\
\text { professional to individuals in the Corona pandemic }\end{array}$ & $50(9.4)$ & $120(22.5)$ & $358(67.0)$ & $19(6.8)$ & $61(21.7)$ & $199(70.8)$ \\
\hline Overall M (SD) & $2.52(0.50)$ & & & $2.55(0.44)$ & & \\
\hline
\end{tabular}

\subsection{Comparison of Participants' Socio-demographic Characteristics With attitudes and Anxiety Score}

As shown in table 6, anxiety was a bit higher among individuals above 35 years old. The difference was only significant for Tunisian. With regard to gender, females of
Palestine and Tunisia scored higher for attitudes and anxiety; however it was only significant in attitudes for Palestinian females and anxiety for Tunisian females. $(\mathrm{p}<0.05)$. Attitude score was higher among individuals, from Palestine and Tunisia, whom held at least university degree but significant was only seen among Tunisian.

Table 6. Comparison of social and demographic characteristics with mean attitudes and anxiety score.

\begin{tabular}{|c|c|c|c|c|c|c|}
\hline & \multicolumn{6}{|l|}{ Attitudes } \\
\hline & \multirow{2}{*}{ M (SD) } & $P$ & $C I(95 \%)$ & M (SD) & $\boldsymbol{P}$ & $C I(95 \%)$ \\
\hline & & Anxiety & Attitude & Anxiety & & \\
\hline$\leq 35$ & $4.26(.48)$ & \multirow{2}{*}{0.32} & \multirow{2}{*}{$-0.12-0.014$} & $2.89(.68)$ & \multirow{2}{*}{0.08} & \multirow{2}{*}{$-0.22-0.01$} \\
\hline$>35$ & $4.30(.47)$ & & & $3.00(.67)$ & & \\
\hline \multicolumn{7}{|l|}{ Gender } \\
\hline Female & $4.32(.48)$ & $0.006^{* *}$ & $0.03-0.2$ & $2.95(.67)$ & 0.64 & $-0.09-0.15$ \\
\hline \multicolumn{7}{|l|}{ Job } \\
\hline $\mathrm{HCW}$ & $4.38(.43)$ & \multirow{6}{*}{$0.04 *$} & \multirow{6}{*}{$F=2.206$} & $3.01(.71)$ & \multirow{6}{*}{0.41} & \multirow{6}{*}{$F=1.011$} \\
\hline Business & $4.05(.50)$ & & & $2.71(.80)$ & & \\
\hline Academia & $4.27(.42)$ & & & $2.96(.65)$ & & \\
\hline Profess / crafts & $4.09(.49)$ & & & $3.01(.53)$ & & \\
\hline Housewife & $4.22(.52)$ & & & $2.95(.62)$ & & \\
\hline Others & $4.27(.50)$ & & & $2.95(.67)$ & & \\
\hline \multicolumn{7}{|l|}{ Education level } \\
\hline$\leq$ secondary school & $4.15(.55)$ & \multirow{2}{*}{0.10} & \multirow{2}{*}{$-0.31-0.028$} & $2.92(.63)$ & \multirow{2}{*}{0.87} & \multirow{2}{*}{$-0.21-0.18$} \\
\hline Higher education & $4.29(.46)$ & & & $2.94(.68)$ & & \\
\hline
\end{tabular}

Table 6. Continue.

\begin{tabular}{|c|c|c|c|c|c|c|}
\hline & \multicolumn{6}{|l|}{ Attitudes } \\
\hline & M (SD) & $P$ & $C I(95 \%)$ & M (SD) & $P$ & $C I(95 \%)$ \\
\hline Age $(\mathrm{M} \pm \mathrm{SD})$ & & & & $3.24(.68)$ & & \\
\hline $\begin{array}{l}\leq 35 \\
>35\end{array}$ & $\begin{array}{l}4.13(.45) \\
4.28(.45)\end{array}$ & $0.01 *$ & $-0.28--0.02$ & $3.47(.70)$ & $0.02 *$ & $-0.42--0.02$ \\
\hline Gender & & & & & & \\
\hline $\begin{array}{l}\text { Male } \\
\text { Female }\end{array}$ & $\begin{array}{l}4.09(.46) \\
4.20(.45)\end{array}$ & 0.06 & $-0.004-0.22$ & $\begin{array}{l}2.99(.69) \\
3.45(.63)\end{array}$ & $<0.001 * *$ & $0.28-0.63$ \\
\hline
\end{tabular}




\begin{tabular}{|c|c|c|c|c|c|c|}
\hline & \multicolumn{6}{|l|}{ Attitudes } \\
\hline & M (SD) & $P$ & CI (95\%) & M (SD) & $P$ & $C I(95 \%)$ \\
\hline $\mathrm{HCW}$ & $4.30(.34)$ & & & $3.51(.52)$ & & \\
\hline Business & $4.21(.54)$ & & & $3.10(.93)$ & & \\
\hline Academia & $4.15(.45)$ & & & $3.17(.73)$ & & \\
\hline Profess / crafts & $4.10(.39)$ & 0.19 & $F=1.461$ & $3.23(.51)$ & 0.77 & $F=0.545$ \\
\hline Student & $4.12(.44)$ & & & $3.30(.65)$ & & \\
\hline Housewife & $4.11(.41)$ & & & $3.43(.83)$ & & \\
\hline Others & $4.33(.51)$ & & & $3.27(.76)$ & & \\
\hline \multicolumn{7}{|l|}{ Education level } \\
\hline$\leq$ secondary school & $3.81(.49)$ & & & $3.49(.92)$ & & \\
\hline Higher education & $4.20(.44)$ & $0.002 * *$ & $-0.57--0.18$ & $3.28(.67)$ & 0.30 & $-0.20-0.62$ \\
\hline
\end{tabular}

$* p \leq 0.05 ; * * p<0.01$

\section{Discussion}

To the best of our knowledge, this is the first study assessing the public attitude and anxiety experience towards the COVID-19 pandemic among two Arabian countries "Palestine and Tunisia" using an online self-reported questionnaire. The study revealed that the vast majority of the public Palestinians (mean=85.6\%) and Tunisians (mean $=83.4 \%$ ) had a positive attitude towards the measures of confrontation and overcoming the COVID-19. Comparing with previous studies, similar positive attitudes were noticed in other Arab countries such as Egypt [24] and Saudi Arabia [5]. More than $95 \%$ of the participants from both countries believed that social distance is necessary to prevent the spread of COVID-19 and ready to isolate/quarantine themselves in case symptoms of fever and cough appear. Such a positive attitude could be attributed to the knowledge acquired through the wide influx of information in either the media or the health education programs and campaigns. However, this explanation might be supported with a conclusion pointed out that higher level of knowledge is associated with higher positive attitudes in health crises [25]. Another possible explanation could be related to the high trust in government actions and its prompt preparedness and response measures to control the COVID-19. This is supported by the current study finding showed that the overwhelmingly vast majority $(94.2 \%$ in Palestine and $92.9 \%$ in Tunisia) agreed about government instructions and interventions related to Covid-19. Furthermore, it is worth pointing that more than $88 \%$ of participants in Palestine and Tunisia were educated and held bachelor or higher degrees. Such a level of education was significantly associated with a positive attitude among Tunisian participants. This finding is consistent with previous finding [26].

Considering the socio-demographic characteristics, the positive attitude was significantly higher among Palestinian females compared with their counterparts. Similar findings were found in Saudi Arabia [5] which showed that females were significantly more likely to have a positive attitude toward the measures of controlling the COVID-19. The analysis pointed out that the Palestinian healthcare workers had significantly higher positive attitude despite they are more likely to contact with suspected and confirmed COVID-19 cases. This could be related to their higher knowledge of social distancing practices, infection prevention and control, and safety measures.

The study also pointed out that a considerable percent of the Palestinian (83.7\%) and Tunisian (74.7\%) participants had mild or moderate anxiety, meanwhile (6.7\%) and $(16.0 \%)$ of the Palestinian and Tunisian respectively experienced severe levels of anxiety. Such anxiety could be attributed to unpredictability, uncertainty, the seriousness of the disease, misinformation and social isolation in contributing to stress and anxiety [27]. During the COVID19 pandemic, people have a fear of infection, dying, or losing a family member [28]. The WHO has expressed its concern over the pandemic's mental health and psycho-social consequences due to COVID-19. It suggests that the new measures of self-isolation and lockdown have influenced the daily routine activities and lifestyle that might result in an increase of anxiety, depression, loneliness, or insomnia [29]. Although currently, the evidence is scarce on the impact of COVID-19 on the mental health of the general population, data showed that the population mental health has been affected, comparing with before the outbreak [30]. A recently published systematic review and meta-analysis on the impact of COVID-19 found that the prevalence of anxiety among the general public and medical staff was 33\% [31]. More than half of the Palestinian and $62.3 \%$ of the Tunisian participants expressed their worrying about themselves and their family members regarding the spread of new coronavirus. In China, more than $75 \%$ of respondents experienced worry about their family members contracting COVID-19 [32]. Approximately half of the Palestinian and Tunisian participants were affected by the talks of news channels and newspapers on the Covid19 pandemic. In disasters such as pandemics, people can easily be exposed to frustrating news or rumors, and this can elevate the level of anxiety. A study showed that people who often follow COVID-19 related news experience more anxiety [33]. Therefore, the WHO encouraged the media not to only broadcast negative or disappointing news [34]. The present study showed that $33.5 \%$ and $43.4 \%$ of the Palestinian and Tunisians respectively, suffered from sleep difficulties due to COVID-19. Previous findings also pointed out that anxiety was associated with impaired sleep [35].

The analysis revealed that the socio-demographic characteristics were not significantly associated with anxiety, except the gender and age among Tunisian participants. The study found that female participants significantly scored higher anxiety compared with their counterparts. This is corroborated 
with other previous studies with similar findings [32, 36-38]. Such finding could be related to the biological sex variations such as the female hormonal fluctuations that might contribute to female's higher anxiety levels [38]. Another possible explanation can be due to the additional roles and stressors the women are bearing during disasters or pandemics, including but not limited to work, taking care of family members, and protecting their children from any risk of being infected. Contrary to our expectation, our study found that healthcare workers didn't significantly experience a higher level of anxiety compared with other jobs. It seems that the Palestinian and Tunisian healthcare workers found their way to cope with the consequence of the COVID-19 pandemic. However, this result was incongruent with previous studies that showed a higher level of anxiety among healthcare workers compared with other jobs $[39,40]$. Such a higher level of anxiety could be due to the risk of infection, long working hours, shortages of personal protective equipment, physical fatigue, loneliness, and separation from families [41].

The study also revealed the perception of the participants towards the role of mental healthcare services towards dealing with COVID-19 pandemic. Majority of the Palestinians $(73.8 \%)$ and $(78.6 \%)$ Tunisians believed in the necessity of seeking mental healthcare services in case of being infected with COVID-19. The WHO recommended the inclusion of mental health and psychosocial considerations in COVID-19 national response because it improves the quality of programming, enhances coping skills of people during the crisis, reduces suffering, and is likely to speed up the recovery and rebuilding of communities [42].

This study has some limitations: due to the infectivity of the COVID-19, a web-based survey was chosen to decrease the chances of transmission; a non-randomized snowball sample was used. Such sampling caused a selection bias as only who can read or had access to the internet has participated. Furthermore, the fact that this is a nonrandomized sampling, hence generalizability is limited. Another limitation, the fact that this is a cross-sectional study, temporal effect can't be measured, hence no causation.

\section{Conclusion}

The study suggests that both Palestinians and Tunisians had a positive attitude towards the COVID-19 pandemic. Females and healthcare workers in Palestine, and the age group $>35$ and high education in Tunisia significantly had a higher positive attitude. Meanwhile, in Palestine, the results showed that COVID-19 has relatively affected the psychological wellbeing of individuals from the entire community including healthcare workers, students, businessmen, academics, and others; both sex; young and old ages; and both with less or higher education. Similarly, in Tunisia, except for females and the age group $>35$ experienced higher anxiety levels. Policymakers and mental care health providers are encouraged to include mental health during disasters and pandemics as a national priority. The public should be educated on the common adverse psychological consequences, healthy behaviors promotion, and seeking mental healthcare services when necessary. Further researches are required to assess the impact of the COVID-19 on the population's mental health and psychological consequences. Further researches are recommended on large sample of population to verify the mental health implications of the COVID-19 pandemic.

\section{Competing Interests}

The author declares that he has no competing interests.

\section{Authors' Contributions}

AE, MR: Conceptualization, Methodology. AE, MR, SN, SB, HT, AS, KM and MA: Data collection, Writing- Original draft preparation. AE: Supervision. AE, SB, KM: Validation, Formal analysis. AE, MR, SN, SB, HT, AS, KM and MA: Reviewing and Editing. All authors approved and agreed upon this manuscript.

\section{Supplementary Materials}

Supplementary material associated with this article is available with corresponding author upon request

\section{Acknowledgements}

The authors are grateful to Palestinians and Tunisian who made this work real.

\section{References}

[1] Abdelhafiz, A. S., Mohammed, Z., Ibrahim, M. E., Ziady, H. H., Alorabi, M., Ayyad, M., et al., 2020. Knowledge, Perceptions, and Attitude of Egyptians Towards the Novel Coronavirus Disease (COVID-19). J Community Health. 21, 1-10.

[2] Al-Hanawi, M. K., Angawi, K., Alshareef, N., Qattan, A. M. N., Helmy, H. Z., Abudawood, Y., etal., 2020. Knowledge, Attitude and Practice Toward COVID-19 Among the Public in theKingdom of Saudi Arabia: A Cross-Sectional Study. Front. Public Health. 8, 217.

[3] AlKhaldi, M., Kaloti, R., Shella, D., Al Basuoni, A., Meghari, $\mathrm{H}$, 2020. Health system's response to the COVID-19 pandemic in conflict settings: Policy reflections from Palestine, Global Public Health.

[4] Alkhamees, A. A., Alrashed, S. A., Alzunaydi, A. A., Almohimeed, A. S., Aljohani, M. S, 2020. The psychological impact of COVID-19 pandemic on the general population of Saudi Arabia. Comprehensive Psychiatry, In press, journal pre-proof, Available online 12 July 2020.

[5] Applegate, W. B., Ouslander, J. G, 2020. COVID-19 presents high risk to older persons. J. Am. Geriat. Soc. 68, 4, 681-681.

[6] Azlan, A. A., Hamzah, M. R., Sern, T. J., Ayub, S. H., Mohamad, E, 2020. Public knowledge, attitudes and practices towards COVID-19: A cross-sectional study in Malaysia. PLOS ONE. 15, 5, e0233668. 
[7] Bao, Y., Sun, Y., Meng, S., Shi, J., Lu, L, 2020. 2019-nCoV epidemic: address mental health care to empower society. Lancet. 395, 10224, e37-e38.

[8] Brooks, S. K., Webster, R. K., Smith, L. E., Woodland, L., Wessely, S., Greenberg, N., et al., 2020. The psychological impact of quarantine and how to reduce it: rapid review of the evidence. Lancet. 395, 912-920.

[9] Fairwear, 2020. COVID-19 impact and responses: Tunisia. Available from: https://www.fairwear.org/covid-19dossier/worker-engagement-and-monitoring/country-specificguidance/tunisia/ (accessed 30 June 2020).

[10] Hayat, K. H., Rosenthal, M., Xu, S., Arshed, M., Li, P., Zhai, P., et al., 2020. View of Pakistani Residents toward Coronavirus Disease (COVID-19) during a Rapid Outbreak: A Rapid Online Survey. Int. J. Environ. Res. Public Health, 17, 10,3347 .

[11] Huang, Y., Zhao, N, 2020b. Chinese mental health burden during the COVID-19 pandemic. Asian J. Psychiatr. 51, 102052 .

[12] Huang, Y., Zhao, N, 2020a. Generalized anxiety disorder, depressive symptoms and sleep quality during COVID-19 outbreak in China: a web-based cross-sectional survey. Psychiatry Res. 288, 112954.

[13] Huynh, G., Nguyen, T. N. H., Tran, V. K., Vo, K. N., Vo, V. T., Pham, L. A, 2020. Knowledge and attitude toward COVID-19 among health care workers at district 2 Hospital, Ho Chi Minh City. Asian. Pac. J. Trop. Med. 13, 6, 260-265.

[14] Kang, L., Li, Y., Hu, S., Chen, M., Yang, C., Yang, B. X., et al., 2020. The mental health of medical workers in Wuhan, China dealing with the 2019 novel coronavirus. Lancet Psychiatry. 7, 3, e14.

[15] Kelvin, D. J., Rubino, S, 2020. Fear of the novel coronavirus. J. Infect. Dev. Ctries. 14, 1, 1-2.

[16] Liu, X., Kakade, M., Fuller, C. J., Fan, B., Fang, Y., Kong, J., et al., 2012. Depression after exposure to stressful events: lessons learned from the severe acute respiratory syndrome epidemic. Comprehensive Psychiatry, 53, 1, 15-23.

[17] Li, W., Yang, Y., Liu, Z., Zha, Y. J., Zhang, Q., Zhang, L., et al., 2020. Progression of Mental Health Services during the COVID19 Outbreak in China. Int. J. Bio. Sci. 16, 10, 1732-1738.

[18] Luo, M., Guo, L., Yu, M., Jiang, W., Wang, H, 2020. The psychological and mental impact of coronavirus disease 2019 (COVID-19) on medical staff and general public - A systematic review and meta-analysis. Psychiatry Res. 291, 113190.

[19] Maarefvand, M., Hosseinzadeh, S., Farmani, O., Farahan, A. S., Khubchandani, J, 2020. Coronavirus Outbreak and Stress in Iranians. J. Environ. Res. Public. Health. 17, 12, E4441.

[20] Moghanibashi-Mansourieh, A, 2020. Assessing the anxiety level of Iranian general population during COVID-19 outbreak. Asian. J. Psychiatr. 51: 102076.

[21] Naser, A. Y., Ahmash, E. Z., Al-Rousan, R., Alwafi, H., Alrawashdeh, H. M., Ghoul, I., et al., 2020. Mental health status of the general population, healthcare professionals, and universitystudents during 2019 coronavirus disease outbreak in Jordan: A cross-sectional study. Brain. Behav. 00: e01730.
[22] Neil, G., Mary, D., Sam, G., Simon, W, 2020. Managing mental health challenges faced by healthcare workers during covid-19 pandemic Br. Med. J. 368: m1211.

[23] Olum, R., Chekwech, G., Wekha, G., Nasoszi, D. R., Bongomin, F, 2020. Coronavirus disease- 2019: Knowledge, attitude, and practices of health care workers at Makerere University mteaching hospitals, Uganda. Front Public Health. 8: 18 .

[24] Pappa, S., Ntella, V., Giannakas, T., Giannakoulis, V. G., Papoutsi, E., Katsaounou, P, 2020. Prevalence of depression, anxiety, and insomnia among healthcare workers during the COVID-19 pandemic: A systematic review and meta-analysis. Brain. Behavior. Immunity.

[25] Shi, Y., Wang, J., Yang, Y., Wang, Z., Wang, G., Hashimoto, K., et al., 2020. Knowledge and attitudes of medical staffin Chinese psychiatric hospitals regarding COVID-19. Brain. Behav. Immun. Health. 4: 100064.

[26] Qiu, J., Shen, B., Zhao, M., Wang, Z., Xie, B., Xu, Y, 2020. A nationwide survey of psychological distress among Chinese people in the COVID-19 epidemic: implications and policy recommendations. General Psychiatry. 33: e100213.

[27] Roy, D., Tripathy, S., Kar, S. K., Sharma, N., Verma, S. K., Kausha, V, 2020. Study of knowledge, attitude, anxiety and perceived mental healthcare need in Indian population during COVID-19 pandemic. Asian J Psychiatr. 51, 102083.

[28] Sanwang, W., Xin, W., Bin, L., Yingying, D., Ming, C, 2020. Psychological influence of Coronovirus disease 2019 (COVID-19) pandemic on the general public, medical workers and patients with mental disorders and its countermeasures. Psychosomatics.

[29] Serafini, G., Parmigiani, B., Amerio, A., Aguglia, A., Sher, L., Amore, M, 2020. The psychological impact of COVID-19 on the mental health in the general population. QJM: An Int. J. Med. hcaa. 201, 1-7.

[30] Sønderskov, K. M., Dinesen, P. T., Santini, Z. I., Østergaard, S. D, 2020. The depressive state of Denmark during the COVID-19 pandemic. Acta Neuropsychiatrica. 1-3.

[31] UNSDG, 2020. Policy Brief: COVID-19 and the Need for Action on Mental Health. Available from: https://unsdg.un.org/sites/default/files/2020-05/UN-PolicyBrief-COVID-19-and-mental-health.pdf (accessed 1st July 2020).

[32] Wang, C., Pan, R., Wan, X., Tan, Y., Xu, L, Ho, C. S., et al., 2020. Immediate psychological responses and associated factors during the initial stage of the 2019 coronavirus disease (COVID-19) epidemic among the general population in China. Int. J. Environ. Res. Publ. Health. 17, 5, 1729.

[33] Warner, M., Gustafsson, J. A., 2015. Estrogen receptor beta and liver X receptor beta: biology and therapeutic potential in CNS diseases. Mol Psychiatry. 20, 1, 18-22.

[34] World Health Organization, 2020a. Coronavirus disease (COVID-2019) situation. reports. https://www.who.int/emergencies/diseases/novel-coronavirus2019/situation-reports (accessed 15 Jun 2020).

[35] World Health Organization, 2020c. Mental health and COVID19. Available from: https://www.euro.who.int/en/healthtopics/health-emergencies/coronavirus-covid-19/technicalguidance/mental-health-and-covid-19 (accessed 26 June 2020). 
[36] World Health Organization, 2020d. Mental health and psychosocial considerations during the COVID-19 outbreak. Available from: https:/www.who.int/docs/defaultsource/coronaviruse/mental-health-

considerations.pdf?sfvrsn $=6 \mathrm{~d} 3578$ af 2 (accessed in 25 June 2020).

[37] World Health Organization, 2020b. Novel Coronavirus (2019ncov) Situation Report-22 Situations; WHO: Geneva, Switzerland. Available from: https://apps.who.int/iris/bitstream/handle/10665/330991/nCoV sitrep11Feb2020-eng.pdf? sequence $=1 \&$ isAllowed $=y$ (accessed 29 June 2020).

[38] Xiang, Y. T., Yang, Y., Li, W., Zhang, L., Zhang, Q., Cheung, T., et al., 2020. Timely mental health care for the 2019 novel coronavirus outbreak is urgently needed. Lancet Psychiatry. 7, $3,228-229$.
[39] Xiao, C., 2020. A novel approach of consultation on 2019 novel coronavirus (COVID-19)- related psychological and mental problems: structured letter therapy. Psychiatry Investig. 17 (2), 175-176.

[40] Zandifar, A., Badrfam, R., 2020. Iranian mental health during the COVID-19 epidemic. Asian. J. Psychiatr. 4, 51, 101990.

[41] Zhang, S. X., Liu, J., Jahanshahi, A., Nawaser, K., Yousefi, A., Li, J, et al., 2020. At the height the storm: healthcare staff's health conditions and job satisfaction and their associated predictors during the epidemic peak of COVID-19. Brain Behav. Immun. (2020).

[42] Zhong, B. L., Luo, W., Li, H. M., Zhang, Q. Q., Liu, X. G., Li, W. T., et al., 2020. Knowledge, attitudes, and practices towards COVID-19 among Chinese residents during the rapid rise period of the COVID-19 outbreak: a quick online crosssectional survey. Int. J. Biol Sci. 10, 1745-1752. 